Referendums and Ethnic Conflict 
National and Ethnic Conflict in the Twenty-First Century

Brendan O’Leary, Series Editor

A complete list of books in the series is available from the publisher. 


\section{Referendums and Ethnic Conflict}

Matt Qvortrup

\section{PENN}

UNIVERSITY OF PENNSYLVANIA PRESS

PHILADELPHIA 
Copyright (C) 2014 University of Pennsylvania Press

All rights reserved. Except for brief quotations used for purposes of review or scholarly citation, none of this book may be reproduced in any form by any means without written permission from the publisher.

Published by

University of Pennsylvania Press

Philadelphia, Pennsylvania 19104-4112

www.upenn.edu/pennpress

Printed in the United States of America on acid-free paper

1098766543321

Library of Congress Cataloging-in-Publication Data

Qvortrup, Matt.

Referendums and ethnic conflict / Matt Qvortrup.

pages $\mathrm{cm}$.- (National and ethnic conflict in the twenty-first century)

Includes bibliographical references and index.

ISBN 978-0-8122-4580-6 (hardcover : alk. paper)

1. Referendum. 2. Ethnic conflict-Political aspects. 3. Ethnic conflictGovernment policy. I. Title.

JF491.Q95 2014

$328.2^{\prime} 3-\mathrm{dc} 23$ 
The existence of a nation is a daily plebiscite.

-Ernest Renan, Qu'est-ce qu'une nation?

Lex est quod populus iubet atque constituit.

—Gaius, Institutiones

The History of the world is not the theatre of happiness. Periods of happiness are blank pages in it, for they are periods of harmony,-_periods when the antithesis is in abeyance.

-G. W. F. Hegel, The Philosophy of History

A Citizen in general is someone who is capable of being a ruler and a subject. -Aristotle, Politics 
